\title{
ANALISIS PENGARUH DISIPLIN KERJA GURU DALAM MELAKSANAKAN PEMBELAJARAN TERHADAP MUTU HASIL BELAJAR SISWA
}

\author{
Oleh \\ Yuli Alam \\ Perguruan Tinggi Bina Sriwijaya Palembang, Sumatera Selatan \\ yulialam78@gmail.com
}

diterima 10 Juli 2018, direvisi 19 Pebruari 2019, diterbitkan 28 Februari 2019

\begin{abstract}
This study aims to analyze the influence of teacher work discipline in implementing learning on quality of student learning outcomes in SMP Negeri 14 Palembang. The respondents in this research are school supervision team, 9th grade teacher (Indonesian, English, Mathematics and Science) and 9th graders of 318 students. Instrument of data collection used is closed questionnaire, interview and student learning outcomes. Data of research result analyzed descriptively and inferensial (using linear regression analysis).The results showed that Indonesian language teacher work discipline influence the students' learning outcomes. As for the subjects of English, Mathematics and Science can be stated there is no influence between the teacher's work discipline on student learning outcomes. One of the factors that determine quality of student learning outcomes is the method of learning. Teaching methods used by teachers should be tailored to the characteristics of learning materials
\end{abstract}

\section{Keywords: Discipline of Teacher Work, Questionnaire, Learning Outcome.}

\section{PENDAHULUAN}

Dalam kehidupan berbangsa dan bernegara, salah satu yang berperan penting adalah pendidikan. Melalui pendidikan dapat menciptakan Sumber Daya Manusia yang berkualitas.

Beberapa faktor yang mempengaruhi keberhasilan pendidikan antara lain: guru, siswa, sarana dan prasarana, lingkungan pendidikan, kurikulum. Dari beberapa faktor tersebut tanpa mengabaikan faktor penunjang yang lain, guru dalam kegiatan proses pembelajaran di sekolah sangat menentukan keberhasilan pendidikan itu sendiri (Widoyoko \& Rinawati, 2012). Oleh karena itu guru sebaiknya menciptakan kegiatan proses pembelajaran yang berkualitas sehingga keberhasilan siswa dapat maksimal.

Syam (2016) juga mengatakan bahwa guru merupakan salah satu komponen yang 
penting dalam meningkatkan kualitas pendidikan, karena guru memiliki peranan yang unik dan sangat komplek di dalam proses pembelajaran dalam usahanya untuk mengantarkan siswa ke taraf yang dicitacitakan. Oleh karena itu guru merupakan salah satu penentu keberhasilan siswa.

Keberhasilan siswa dapat dilihat dari mutu hasil belajar. Mutu hasil belajar berupa nilai/angka yang diperoleh selama proses belajar. Nilai tersebut mencerminkan tingkat keberhasilan siswa. Selain aspek pengetahuan, keterampilan dan sikap profesional, ada karakteristik psikologi individu yang sangat berperan dalam meningkatkan prestasi siswa yaitu disiplin kerja guru (Abdul Naser, 2012). Disiplin kerja guru meliputi kehadiran guru di kelas, disiplin guru dalam memberikan tugas dan menindaklanjuti tugas yang diberikan, sikap guru terhadap siswa saat siswa tidak mengerjakan tugas, penggunaan metode pembelajaran yang bervariatif, kejelasan guru dalam menerangkan materi pelajaran, guru mengarahkan siswa agar aktif dalam proses pembelajaran dan guru membimbing siswa dalam membuat kesimpulan di akhir pembelajaran. Dalam hal ini disiplin kerja guru merupakan cara guru dalam melaksanakan pembelajaran di kelas.

Beberapa penelitian sebelumnya melaporkan bahwa: hasil belajar siswa sebesar 76,6\% dipengaruhi oleh kinerja guru, dengan rincian: kemampuan guru mengajar memberikan sumbangan 32,43\%; penguasaan materi pelajaran memberikan sumbangan $32,38 \%$; dan sikap guru terhadap mata pelajaran memberikan sumbangan $8,60 \%$ (Sudjana, 2002). Selain itu, Senduperdana (2007) juga menyatakan bahwa kualitas pembelajaran mempengaruhi hasil belajar siswa. Pembelajaran yang berkualitas akan tercapai apabila guru mempunyai kompetensi dan kinerja yang baik. Hal ini membuktikan bahwa faktor utama dalam pendidikan adalah guru. Dengan demikian, guru yang berkualitas baik akan menciptakan kualitas pembelajaran yang maksimal, begitu juga sebaliknya.
Kinerja guru meliputi perencanaan, pelaksanaan dan evaluasi pembelajaran. Semakin besar usaha guru dalam aspek perencanaan, pelaksanaan, dan evaluasi pembelajaran, semakin besar peluang guru untuk meningkatkan skor hasil belajar siswa, Asmawati (2017). Oleh karena itu sangat diperlukan penilaian kinerja guru untuk mengetahui baik atau kurangnya kualitas pengajaran yang dilakukan guru dalam melaksanakan kegiatan pembelajaran di kelas.

Penilaian kinerja guru (perencanaan, pelaksanaan, dan evaluasi pembelajaran) dapat dilakukan oleh tim supervisi sekolah, penilaian diri sendiri dan penilaian siswa. Penilaian siswa diperlukan karena siswa mengetahui dan merasakan baik atau tidaknya pembelajaran di kelas. Penilaian disiplin kerja guru yang dilakukan oleh siswa dengan cara pengisian angket tertutup. Hal ini dilakukan berdasarkan observasi peneliti di lapangan dan penelitian sebelumnya yaitu Asmawati (2017) yang menyatakan bahwa sebagian besar guru sudah baik dalam perencanaan namun pelaksanaannya tidak sesuai dengan perencanaan yang telah dirancang sebelumnya.

Nurmiati (2013) menyatakan bahwa kinerja guru yang positif atau tinggi akan meningkatkan hasil belajar ekonomi siswa dan sebaliknya jika kinerja guru negatif atau jelek maka akan menurunkan hasil belajar siswa. Sebelumnya Abdul Naser (2012) juga telah menyatakan bahwa ada hubungan disiplin kerja guru dengan prestasi yang diraih oleh siswa.

Berbeda dengan penelitian sebelumnya yang hanya menyelidiki pengaruh kinerja guru terhadap hasil belajar siswa dan hubungan disiplin kerja guru terhadap prestasi belajar siswa untuk satu mata pelajaran. Penelitian ini menganalisis pengaruh disiplin kerja guru dalam melaksanakan pembelajaran terhadap mutu hasil belajar siswa untuk empat mata pelajaran yaitu Bahasa Indonesia, Bahasa Inggris, Matematika, dan IPA. 
Penelitian ini dilaksanakan di salah satu SMP Negeri di kecamatan Sako Palembang, yaitu SMP Negeri 14 Palembang. Berdasarkan observasi peneliti, SMP ini merupakan SMP favorit diantara lima SMP Negeri di kecamatan Sako karena letaknya strategis, disiplin terhadap tata tertib sekolah dan guru - gurunya sudah berpengalaman dalam mengajar dan profesional.

Berdasarkan uraian di atas, sehingga penelitian ini bertujuan untuk "menganalisis pengaruh disiplin kerja guru dalam melaksanakan pembelajaran terhadap mutu hasil belajar siswa SMP Negeri 14 Palembang untuk mata pelajaran Bahasa Indonesia, Bahasa Inggris, Matematika, dan IPA"

\section{METODE}

Berdasarkan segi pendekatan yang digunakan, penelitian ini merupakan penelitian kuantitatif sedangkan dilihat dari permasalahan yang diambil dan tujuan penelitian, sehingga penelitian ini bersifat ex-post facto.

Penelitian ini dilaksanakan di SMP Negeri 14 Palembang pada semester ganjil tahun pelajaran 2017/2018. Responden yang terlibat dalam penelitian ini adalah tim supervisi sekolah, guru kelas IX untuk mata pelajaran Bahasa Indonesia, Bahasa Inggris, Matematika dan IPA yang masing-masing berjumlah 3 orang dan siswakelas IX yang berjumlah 318 orang. Sampel responden siswa dipilih secara acak diantara kelas VII, VII dan IX.

Penelitian ini terdiri dari dua variabel yaitu disiplin kerja guru empat mata pelajaran (Bahasa Indonesia, Bahasa Inggris, Matematika dan IPA) dalam melaksanakan pembelajaran yang merupakan variabel bebas dan mutu hasil belajar siswa untuk keempat mata pelajaran tersebut yang merupakan variabel terikat.

Teknik pengumpulan data dalam penelitian ini adalah angket tertutup mengenai penilaian disiplin kerja guru dalam melaksanakan pembelajaran di kelas dan wawancara. Angket tertutup merupakan serangkaian pertanyaan yang telah dilengkapi alternatif jawaban. Angket tersebut diberikan kepada tim supervisi sekolah, guru sebagai penilaian diri sendiri dan siswa karena siswalah yang mengetahui dan merasakan bagaimana cara guru mengajar di kelas. Selanjutnya mutu hasil belajar yang diambil adalah nilai raport semester ganjil tahun pelajaran 2017/2018.

Angket tentang penilaian disiplin kerja guru diolah dan diinterpretasikan hasilnya berdasarkan skala Likert. Jawaban dari setiap item pada instrumen menggunakan skala Likert yang mempunyai gradasi dari sangat positif sampai negatif yang berupa kata kata yaitu (a) Sering Sekali, skor 5; (b) Sering, skor 4; (c) Kadang - kadang, skor 3; (d) Jarang, skor 2 dan (e) Tidak Pernah, skor 1.

Setelah instrumen penelitian dirancang, dilakukan pengujian validitas dan reliabilitas. Uji validitas menggambarkan bahwa pernyataan yang digunakan mampu untuk mengungkapkan sesuatu yang akan diukur (valid). Uji validitas instrumen pada penelitian ini adalah validitas konstruk (contruct validity). Pengujian validitas kontruk menggunakan analisis faktor dengan cara menghitung koefisien korelasi (r) antara skor butir dengan skor total. Jika nilai "r" lebih dari 0,3 maka nomor butir tersebut dinyatakan valid (Fernandes, 1984). Berdasarkan hasil analisis menunjukkan bahwa dari 20 butir instrument, 5 instrumen dinyatakan tidak valid sehingga penelitian ini menggunakan 15 butir instrumen.

Selanjutnya, uji reliabilitas instrumen pada penelitian ini menggunakan pengujian internal consistency dengan teknik Alpha Cronbach, sekurang - kurangnya 0,7 (Kaplan \& Saccuzzo, 1982). Berdasarkan hasil analisis koefisien reabilitas instrumen yang diperoleh lebih dari 0,7. Instrumen disiplin kerja guru memiliki koefisien Alpha sebesar 0,8299 sedangkan instrumen mutu hasil belajar memiliki koefisien Alpha sebesar 0,7965. Sehingga dinyatakan bahwa instrumen yang digunakan pada penelitian ini memiliki tingkat reliabilitas yang tinggi (reliable). 
Teknik analisis data yang digunakan adalah analisis deskriptif dan analisis inferensial. Analisis inferensial menggunakan regresi linear. Proses analisis menggunakan bantuan program Ms. Excel for windows.
Data hasil penelitian yang dideskripsikan terdiri dari dua variabel yaitu variabel bebas dan variabel terikat.Disiplin kerja guru (X) sebagai variabel bebas dan mutu hasil belajar siswa (Y) sebagai variabel terikat.

\section{HASIL DAN PEMBAHASAN}

Tabel 1. Deskripsi Variabel Disiplin Kerja Guru dan Mutu Hasil Belajar Siswa.

\begin{tabular}{|c|c|r|r|c|r|c|c|}
\hline \multirow{2}{*}{ No } & \multirow{2}{*}{ Variabel } & \multicolumn{3}{|c|}{ Bahasa Indonesia } & \multicolumn{3}{c|}{ Bahasa Inggris } \\
\cline { 3 - 8 } & Mean & TCR & Kategori & Mean & TCR & Kategori \\
\hline 1 & $\begin{array}{c}\text { Disiplin } \\
\text { Kerja Guru }\end{array}$ & 4,31 & 76,13 & Baik & 4,44 & 78,88 & Baik \\
\hline 2 & $\begin{array}{c}\text { Mutu Hasil } \\
\text { Belajar }\end{array}$ & 76,86 & & Baik & 79,67 & & Baik \\
\hline
\end{tabular}

\begin{tabular}{|c|c|r|c|c|r|c|c|}
\hline \multirow{2}{*}{ No } & \multirow{2}{*}{ Variabel } & \multicolumn{3}{|c|}{ Matematika } & \multicolumn{3}{|c|}{ IPA } \\
\cline { 3 - 8 } & Mean & TCR & Kategori & Mean & TCR & Kategori \\
\hline 3 & $\begin{array}{c}\text { Disiplin } \\
\text { Kerja Guru }\end{array}$ & 4,41 & 78,27 & Baik & 3,69 & 73,89 & Baik \\
\hline 4 & $\begin{array}{c}\text { Mutu Hasil } \\
\text { Belajar }\end{array}$ & 74,75 & & Baik & 72,96 & & Baik \\
\hline
\end{tabular}

Berdasarkan tabel 1 di atas, dinyatakan bahwa disiplin kerja guru SMP Negeri 14 Palembang dalam melaksanakan pembelajaran untuk mata pelajaran Bahasa Indonesia adalah 76,13, hal ini bermakna bahwa disiplin kerja guru untuk mata pelajaran ini berkegori baik dan mutu hasil belajar yang diperoleh siswa adalah 76,86 juga berkategori baik.

Untuk variabel disiplin kerja guru Bahasa Inggris adalah 78,88 yang bermakna bahwa disiplin kerja guru Bahasa Inggris dalam melaksanakan pembelajaran berkategori baik dan mutu hasil belajar yang diperoleh siswa adalah 79,67 juga berkategori baik.

Selanjutnya variabel disiplin kerja guru Matematika adalah 78,27. Hal ini menyatakan bahwa disiplin kerja guru Matematika dalam melaksanakan pembelajaran di kelas berkategori baik dan mutu hasil belajar yang diperoleh adalah 74,77 , ini bermakna bahwa mutu hasil belajar yang diperoleh siswa untuk mata pelajaran matematika juga berkategori baik.

Untuk variabel disiplin kerja guru mata pelajaran IPA adalah 73,89, yang bermakna bahwa disiplin kerja guru dalam melaksanakan pembelajaran untuk mata pelajaran IPA berkategori baik. Kemudian mutu hasil belajar untuk mata pelajaran ini adalah 72,96, yang bermakna bahwa mutu hasil belajar yang diperoleh siswa juga berkategori baik.

Dari keempat mata pelajaran yang diselidiki disiplin kerja gurunya, dapat dinyatakan disiplin kerja guru Bahasa Indonesia, Bahasa Inggris, Matematika dan IPA berkategori baik berdasarkan penilaian tim supervisi, penilaian guru (diri sendiri) dan siswa. Selanjutnya mutu hasil belajar untuk keempat mata pelajaran ini juga berkategori baik.

Indikator disiplin kerja guru dalam melaksanakan pembelajaran terdiri dari 15 sub indikator yaitu : (1) kehadiran guru di sekolah, (2) kedatangan guru pada saat jam pelajaran di kelas, (3) keberadaan guru di kelas saat jam pelajaran, (4) penguasaan materi pelajaran, (5) metode pembelajaran yang digunakan guru, (6) apersepsi di awal pembelajaran, (7) penggunaan media dan alat peraga, (8) kesempatan bertanya yang diberikan kepada siswa tentang materi pelajaran, (9) kesempatan siswa lain untuk 
menanggapi pertanyaan temannya, (10) pembahasan tugas di kelas, (11) mengontrol pekerjaan siswa secara langsung, (12) Komentar guru terhadap jawaban atau tugas siswa, (13) penarikan kesimpulan di akhir pembelajaran, (14) sikap guru di kelas dan (15) sikap siswaatau penilaian siswa terhadap guru mata pelajaran.
Penilaian disiplin kerja guru dalam melaksanakan pembelajaran di kelas dilakukan oleh tim supervisi sekolah, penilaian guru (diri sendiri) dan penilaian siswa. Berikut ini adalah tabel penilaian disiplin kerja guru untuk mata pelajaran Bahasa Indonesia.

Tabel 2. Disiplin kerja guru mata pelajaran Bahasa Indonesia

\begin{tabular}{|c|c|c|c|}
\hline No & Indikator Disiplin Kerja Guru & Mean & Kategori \\
\hline 1 & Kehadiran guru di sekolah & 88,46 & Sangat Baik \\
\hline 2 & Kehadiran guru di kelas & 89,23 & Sangat Baik \\
\hline 3 & Keberadaan guru di kelas saat jam pelajaran & 88,97 & Sangat Baik \\
\hline 4 & Penguasaan materi pelajaran & 81,02 & Baik \\
\hline 5 & Metode pembelajaran yang digunakan guru & 81,28 & Baik \\
\hline 6 & Apersepsi di awal pembelajaran & 77,94 & Baik \\
\hline 7 & Penggunaan media dan alat peraga & 64,87 & Cukup Baik \\
\hline 8 & $\begin{array}{l}\text { Kesempatan bertanya yang diberikan kepada } \\
\text { siswa tentang materi pelajaran }\end{array}$ & 78,97 & Baik \\
\hline 9 & $\begin{array}{l}\text { Kesempatan siswa lain untuk menanggapi } \\
\text { pertanyaan temannya }\end{array}$ & 77,43 & Baik \\
\hline 10 & Pembahasan tugas di kelas & 75,13 & Baik \\
\hline 11 & Mengontrol pekerjaan siswa secara langsung & 72,05 & Baik \\
\hline 12 & $\begin{array}{l}\text { Komentar guru terhadap jawaban atau tugas } \\
\text { siswa }\end{array}$ & 80,76 & Baik \\
\hline 13 & Penarikan kesimpulan di akhir pembelajaran & 67,69 & Cukup Baik \\
\hline 14 & Sikap guru di kelas & 77,94 & Baik \\
\hline 15 & $\begin{array}{l}\text { Sikap atau penilaian siswa terhadap guru mata } \\
\text { pelajaran }\end{array}$ & 60,25 & Cukup Baik \\
\hline
\end{tabular}

Tabel 2 menunjukkan penilaian sub indikator disiplin kerja guru Bahasa Indonesia dalam melaksanakan pembelajaran. Guru kelas IX SMP Negeri 14 Palembang terdiri dari 3 orang yang mempunyai kualifikasi pendidikan $\mathrm{S} 1$ dan sudah menjalani tugas mengajar rata - rata lebih dari 20 tahun. Untuk sub indikator kehadiran guru berkategori sangat baik namun ada 3 sub indikator yang berkategori cukup baik yang harus ditingkatkan disiplin kerjanya yaitu penggunaan media atau alat peraga, penarikan kesimpulan diakhir pembelajaran dan sikap atau penilaian siswa terhadap guru mata pelajaran. Guru Bahasa Indonesia sebaiknya selalu menggunaan media atau alat peraga dalam proses pembelajaran di kelas. Hal ini bertujuan agar siswa bersemangat dalam belajar dan mudah memahami materi yang telah disampaikan. Setelah siswa memahami materi maka mutu hasil belajarpun akan meningkat.

Selanjutnya untuk sub indikator penarikan kesimpulan di akhir pembelajaran, sangat perlu ditingkatkan. Kebiasaan yang tidak baik, guru di setiap akhir pembelajaran langsung memberikan tugas dirumah. Seharusnya guru harus memotivasi siswa untuk membuat kesimpulan tentang materi yang telah diperlajari kemudian barulah guru menyempurnakan kesimpulan tersebut. Hal ini harus dilakukan secara rutin disetiap akhir pembelajaran, kemudian barulah guru memberikan tugas di rumah..

Peneliti melakukan wawancara dengan siswa tentang penilaian sikap siswa terhadap 
guru mata pelajaran Bahasa Indonesia.Kenapa siswa sepertinya kurang menyukai guru mata pelajaran ini.Sebagian besar siswa mengatakan "guru ini memang sudah baik dalam menyampaikan materi, tetapi kami bosan dan jenuh karena guru ini sebelum mengajar selalu ceramah dan apapun dibahas". Lalu peneliti bertanya kembali "Maksudnya apapun?". Siswa menjawab : "Itu Bu, maksudnya yang tidak ada kaitannya dengan Bahasa Indonesia". Oleh karena itu dalam proses pembelajaran guru sebaiknya tidak membahas hal - hal yang tidak ada kaitannya dengan materi atau

sudah lama dan pengalaman dalam mengajar tidak menjamin disiplin kerjanya maksimal dalam kategori sangat baik dan belum tentu siswa menyenangi cara mengajar guru tersebut.

Berikut ini adalah tabel penilaian disiplin kerja guru untuk mata pelajaran Bahasa Inggris, berdasarkan penilaian tim supervisi, penilaian diri sendiri dan penilaian siswa. Guru Bahasa Inggris kelas IX SMP Negeri 14 Palembang berjumlah 3 orang yang mempunyai kualifikasi pendidikan $\mathrm{S} 1$ dan sudah menjalani tugas mengajar rata - rata sekitar 15 tahun.

Tabel 3. Disiplin Kerja Guru Mata Pelajaran Bahasa Inggris

\begin{tabular}{|c|l|c|c|}
\hline No & \multicolumn{1}{|c|}{ Indikator Disiplin Kerja Guru } & Mean & Kategori \\
\hline 1 & Kehadiran guru di sekolah & 88,38 & Sangat Baik \\
\hline 2 & Kehadiran guru di kelas & 84,87 & Baik \\
\hline 3 & Keberadaan guru di kelas saat jam pelajaran & 86,41 & Sangat Baik \\
\hline 4 & Penguasaan materi pelajaran & 80,25 & Baik \\
\hline 5 & Metode pembelajaran yang digunakan guru & 79,23 & Baik \\
\hline 6 & Apersepsi di awal pembelajaran & 79,74 & Baik \\
\hline 7 & Penggunaan media dan alat peraga & 75,64 & Baik \\
\hline 8 & $\begin{array}{l}\text { Kesempatan bertanya yang diberikan kepada siswa } \\
\text { tentang materi pelajaran }\end{array}$ & 81,79 & Baik \\
\hline 9 & $\begin{array}{l}\text { Kesempatan siswa lain untuk menanggapi } \\
\text { pertanyaan temannya }\end{array}$ & 69,48 & Cukup Baik \\
\hline 10 & Pembahasan tugas di kelas & 88,94 & Sangat Baik \\
\hline 11 & $\begin{array}{l}\text { Mengontrol pekerjaan siswa secara langsung } \\
\text { Komentar guru terhadap jawaban atau tugas siswa }\end{array}$ & 80,25 & Baik \\
\hline 12 & Komaik \\
\hline 13 & Penarikan kesimpulan di akhir pembelajaran & 63,83 & Cukup Baik \\
\hline 14 & Sikap guru di kelas & 73,58 & Baik \\
\hline 15 & $\begin{array}{l}\text { Sikap atau penilaian siswa terhadap guru mata } \\
\text { pelajaran }\end{array}$ & 73,07 & Baik \\
\hline
\end{tabular}

Berdasarkan tabel 3, disiplin kerja guru Bahasa Inggris kelas IX SMP Negeri 14 Palembang untuk sub indikaor kehadiran dan pembahasan tugas dikelas berkategori sangat baik namun ada dua sub indikator yang berkategori cukup baik sehingga perlu peningkatan disiplinnya yaitu kesempatan siswa lain untuk menanggapi pertanyaan temannya dan penarikan kesimpulan di akhir pembelajaran. Guru sebaiknya memotivasi siswa supaya aktif dalam pembelajaran. Salah satunya memberikan kesempatan kepada siswa yang lain jika salah satu siswa bertanya. Pertanyaan yang diberikan oleh siswa tidak boleh langsung dijawab atau ditanggapi oleh guru. Dengan memberikan kesempatan kepada siswa berkomentar atau memberikan pendapat mereka, merupakan salah satu upaya agar pembelajaran di kelas menjadi lebih aktif.

Kemudian penarikan kesimpulan di akhir pembelajaran merupakan salah satu bagian yang penting dari proses pembelajaran. Guru dan siswa harus bersama 
- sama membuat kesimpulan tentang apa yang telah dipelajari.

Berikut ini adalah tabel penilaian disiplin kerja guru untuk mata pelajaran Matematika, berdasarkan penilaian tim supervisi, penilaian diri sendiri dan penilaian siswa. Guru Matematika kelas IX SMP Negeri 14 Palembang berjumlah 3 orang yang mempunyai kualifikasi pendidikan S1 dan sudah menjalani tugas mengajar rata rata sekitar 25 tahun.

Tabel 4. Disiplin Kerja Guru Mata Pelajaran Matematika

\begin{tabular}{|c|l|c|c|}
\hline No & \multicolumn{1}{|c|}{ Indikator Disiplin Kerja Guru } & Mean & Kategori \\
\hline 1 & Kehadiran guru di sekolah & 79,48 & Baik \\
\hline 2 & Kehadiran guru di kelas & 81,79 & Baik \\
\hline 3 & Keberadaan guru di kelas saat jam pelajaran & 80,22 & Baik \\
\hline 4 & Penguasaan materi pelajaran & 84,61 & Baik \\
\hline 5 & Metode pembelajaran yang digunakan guru & 75,38 & Baik \\
\hline 6 & Apersepsi di awal pembelajaran & 76,92 & Baik \\
\hline 7 & Penggunaan media dan alat peraga & 80,25 & Baik \\
\hline 8 & $\begin{array}{l}\text { Kesempatan bertanya yang diberikan kepada siswa } \\
\text { tentang materi pelajaran }\end{array}$ & 85,64 & Sangat Baik \\
\hline 9 & $\begin{array}{l}\text { Kesempatan siswa lain untuk menanggapi } \\
\text { pertanyaan temannya }\end{array}$ & 77,69 & Baik \\
\hline 10 & Pembahasan tugas di kelas & 84,10 & Baik \\
\hline 11 & Mengontrol pekerjaan siswa secara langsung & 75,64 & Baik \\
\hline 12 & Komentar guru terhadap jawaban atau tugas siswa & 66,15 & Cukup Baik \\
\hline 13 & Penarikan kesimpulan di akhir pembelajaran & 72,30 & Baik \\
\hline 14 & Sikap guru di kelas & 72,05 & Baik \\
\hline 15 & $\begin{array}{l}\text { Sikap atau penilaian siswa terhadap guru mata } \\
\text { pelajaran }\end{array}$ & 81,79 & Baik \\
\hline
\end{tabular}

Berdasarkan tabel 4, sebagian besar sub indikator disiplin kerja guru Matematika kelas IX SMP Negeri 14 Palembang berkategori baik. Hanya ada satu sub indikator yang berkategori cukup baik yang perlu ditingkatkan disiplin kerjanya yaitu komentar guru terhadap jawaban atau tugas siswa. Setelah siswa mengumpulkan jawaban ataupun tugas mereka, sebagai guru berkewajiban menilai tugas tersebut.Dalam menilai tugas siswa, guru bukan hanya mencentang jika benar dan menyilang jika salah. Sebaiknya guru memberikan komentar atau merespon apa yang siswa jawab, baik itu benar maupun salah. Pada saat siswa sudah tepat dalam menjawab atau mengerjakan tugas, sebaiknya guru memberikan pujian, dan begitu juga sebaliknya. Dalam pelajaran matematika, misalnya siswa tidak membuat rumus guru berkomentar "buat rumus terlebih dahulu" kemudian jika siswa langsung ke penyelesaian sebaiknya guru berkomentar "sebaiknya dibuat hal-hal diketahui berdasarkan soal yang diberikan baru ke penyelesaian". Jika siswa salah dalam menghitung sebaiknya guru berkomentar "hati-hati dalam perhitungan". Komentar guru dapat juga memotivasi siswa untuk memperbaiki diri karena siswa menyadari kesalahan ataupun kekeliruan mereka. Sehingga nilai yang siswa peroleh dapat meningkat.

Berikut ini adalah tabel penilaian disiplin kerja guru untuk mata pelajaran IPA, berdasarkan penilaian tim supervisi, penilaian diri sendiri dan penilaian siswa. Guru IPA kelas IX SMP Negeri 14 Palembang berjumlah 3 orang yang mempunyai kualifikasi pendidikan S1 dan sudah menjalani tugas mengajar rata - rata sekitar 25 tahun. 
Tabel 5. Disiplin Kerja Guru Mata Pelajaran IPA

\begin{tabular}{|c|l|c|c|}
\hline No & \multicolumn{1}{|c|}{ Indikator Disiplin Kerja Guru } & Mean & Kategori \\
\hline 1 & Kehadiran guru di sekolah & 74,21 & Baik \\
\hline 2 & Kehadiran guru di kelas & 87,36 & Sangat Baik \\
\hline 3 & Keberadaan guru di kelas saat jam pelajaran & 74,73 & Baik \\
\hline 4 & Penguasaan materi pelajaran & 80 & Baik \\
\hline 5 & Metode pembelajaran yang digunakan guru & 72,63 & Baik \\
\hline 6 & Apersepsi di awal pembelajaran & 68,42 & Cukup Baik \\
\hline 7 & Penggunaan media dan alat peraga & 62,63 & Cukup Baik \\
\hline 8 & $\begin{array}{l}\text { Kesempatan bertanya yang diberikan kepada siswa } \\
\text { tentang materi pelajaran }\end{array}$ & 91,05 & Sangat Baik \\
\hline 9 & $\begin{array}{l}\text { Kesempatan siswa lain untuk menanggapi } \\
\text { pertanyaan temannya }\end{array}$ & 65,78 & Cukup Baik \\
\hline 10 & Pembahasan tugas di kelas & 95,78 & Sangat Baik \\
\hline 11 & Mengontrol pekerjaan siswa secara langsung & 72,65 & Baik \\
\hline 12 & Komentar guru terhadap jawaban atau tugas siswa & 67,89 & Cukup Baik \\
\hline 13 & Penarikan kesimpulan di akhir pembelajaran & 62,63 & Cukup Baik \\
\hline 14 & Sikap guru di kelas & 61,57 & Cukup Baik \\
\hline 15 & $\begin{array}{l}\text { Sikap atau penilaian siswa terhadap guru mata } \\
\text { pelajaran }\end{array}$ & 71,05 & Baik \\
\hline
\end{tabular}

Berdasarkan tabel 5, disiplin kerja guru IPA SMP Negeri 14 Palembang untuk sub indikator kehadiran, kesempatan bertanya dan pembahasan tugas di kelas berkategori sangat baik namun ada lima sub indikator penilailan yang berkategori cukup baik. Kelima sub indikator tersebut harus ditingkatkan disiplin kerjanya yaitu apersepsi diawal pembelajaran, penggunaan media atau peraga, kesempatan siswa lain untuk menanggapi pertanyaan temannya, komentar guru terhadap jawaban atau tugas siswa dan sikap guru di kelas (guru kurang tegas dan kurang disiplin).

Apersepsi diawal pembelajaran sangat penting dilakukan sehingga baik mengingat kembali apa yang telah dipelajari. Begitu juga dengan penggunaan media atau alat peraga, sangat penting dalam menunjang kegiatan belajar mengajar di kelas. Bukan hanya gambar yang ada di buku paket saja.

Disiplin kerja guru dalam memberikan kesempatan bertanya berkategori sangat baik namun disiplin kerja untuk sub indikator memberikan kesempatan kepada siswa lain berkategori cukup baik. Hal ini harus diperbaiki karena guru sebaiknya selalu memberikan kesempatan siswa lain untuk berkomentar apabila ada temannya yang bertanya atau memberi masukan. Dengan demikian dapat memotivasi siswa agar lebih aktif dalam belajar.

Kemudian tugas dan jawaban siswa sebaiknya diberi tanggapan oleh guru baik benar maupun kurang tepat. Sehingga siswa mengetahui dan memperbaiki kesalahan mereka pada saat mengerjakan tugas. Selanjutnya penarikan kesimpulan di akhir pembelajaran merupakan hal yang penting dilakukan disetiap kegiatan belajar mengajar. Guru bersama siswa membuat kesimpulan tentang materi yang telah dipelajari. Kemudian sikap seorang guru sebaiknya tegas dan disiplin sehingga siswa juga disiplin dalam belajar.

Berikut ini adalah hasil analisis regresi disiplin kerja guru masing - masing mata pelajaran terhadap mutu hasil belajar yang diperoleh siswa. 
Tabel 6. Hasil Analisis Regresi, Disiplin Kerja Guru Bahasa Indonesia terhadap Mutu Hasil Belajar Siswa

SUMMARY OUTPUT

\begin{tabular}{|l|r|}
\hline \multicolumn{2}{|c|}{ Regression Statistics } \\
\hline Multiple R & 0.265168 \\
\hline R Square & 0.070314068 \\
\hline Adjusted R Square & 0.058081358 \\
\hline Standard Error & 9.222021849 \\
\hline Observations & 318 \\
\hline
\end{tabular}

ANOVA

\begin{tabular}{|l|r|r|r|r|r|}
\hline & & & & & Significance \\
& Df & SS & MS & $F$ & F \\
\hline Regression & 1 & 488.8457593 & 488.8457593 & 5.748037046 & 0.018962932 \\
\hline Residual & 316 & 6463.472211 & 85.04568698 & & \\
\hline Total & 317 & 6952.31797 & & & \\
\hline & Coefficients & $\begin{array}{c}\text { Standard } \\
\text { Error }\end{array}$ & t Stat & P-value & \\
\hline Intercept & 48.03770693 & 15.92538382 & 3.01642381 & 0.003477617 & \\
\hline $\begin{array}{l}\text { Disiplin } \\
\text { Kerja Guru } \\
\text { B.Ind }\end{array}$ & & & & & \\
\hline
\end{tabular}

Berdasarkan tabel 6, hasil analisis regresi linear antara disiplin kerja guru dalam melaksanakaan pembelajaran Bahasa Indonesia terhadap mutu hasil belajar siswa diperoleh nilai korelasi sebesar 0,26 . Hal ini menyatakan bahwa hubungan antara variabel disiplin kerja dalam melaksanakan pembelajaran Bahasa Indonesia dengan mutu hasil belajar lemah. Koefisien determinan $\left(\mathrm{R}^{2}\right)$ sebesar 0,070; yang bearti bahwa besarnya pengaruh yang diberikan oleh disiplin kerja guru Bahasa Indonesia terhadap mutu hasil belajar siswa sebesar 0,070 atau $7 \%$ sedangkan sisanya $93 \%$ dipengaruhi oleh faktor lain.

Persamaan regresi antara disiplin kerja guru Bahasa Indonesia dan mutu hasil belajar adalah $\mathrm{Y}=48,04+0,49 \mathrm{X}$. Nilai koefisien regresi (b) sebesar 0,49 dengan $t$ hitung 2,397 dan nilai signifikansi p-value sebesar 0,018. Koefisien regresi bernilai positif menunjukkan bahwa arah pengaruhnya positif, artinya semakin baik disiplin kerja guru Bahasa Indonesia maka mutu hasil belajar untuk mata pelajaran Bahasa Indonesia juga akan semakin baik. Selanjutnya nilai p-value sebesar 0,018 < 0,05 , sehingga dapat dinyatakan bahwa ada pengaruh antara disiplin kerja guru Bahasa Indonesia terhadap mutu hasil belajar siswa khususnya mata pelajaran Bahasa Indonesia. Semakin baik disiplin kerja guru dalam melaksanakan pembelajaran maka akan semakin maksimal mutu hasil belajar yang diperoleh siswa.

Tabel 7. Hasil Analisis Regresi, Disiplin Kerja Guru Bahasa Inggris terhadap Mutu Mutu Hasil Belajar Siswa

\begin{tabular}{|l|r|}
\hline \multicolumn{2}{|c|}{ Regression Statistics } \\
\hline Multiple R & 0.094106172 \\
\hline R Square & 0.008855972 \\
\hline
\end{tabular}




\begin{tabular}{|l|r|}
\hline Adjusted R Square & -0.017931705 \\
\hline Standard Error & 2.633879522 \\
\hline Observations & 318 \\
\hline
\end{tabular}

ANOVA

\begin{tabular}{|c|c|c|c|c|c|}
\hline & $D f$ & $S S$ & $M S$ & $F$ & $\begin{array}{c}\text { Significance } \\
F\end{array}$ \\
\hline Regression & 1 & 2.293469551 & 2.293469551 & 0.33059872 & 0.568786875 \\
\hline Residual & 316 & 256.6808894 & 6.937321336 & & \\
\hline \multirow[t]{2}{*}{ Total } & 317 & 258.974359 & & & \\
\hline & Coefficients & $\begin{array}{c}\text { Standard } \\
\text { Error }\end{array}$ & t Stat & $P$-value & \\
\hline Intercept & 82.3125 & 7.46762283 & 11.02258401 & 3.0243113 & \\
\hline $\begin{array}{l}\text { Disiplin Kerja } \\
\text { Guru B. } \\
\text { Inggris }\end{array}$ & $\begin{array}{r}- \\
0.04822716 \\
3\end{array}$ & 0.083876661 & $0.574977147^{-}$ & 0.568786875 & \\
\hline
\end{tabular}

Berdasarkan tabel 7, hasil analisis regresi linear antara disiplin kerja guru dalam melaksanakan pembelajaran Bahasa Inggris dengan mutu hasil belajar siswanya, diperoleh nilai korelasi sebesar 0,094. Hal ini berarti hubungan antara variabel disiplin kerja guru dengan mutu hasil belajar untuk mata pelajaran ini sangat lemah.Koefisien determinan $\left(\mathrm{R}^{2}\right)$ sebesar 0,009; yang bearti bahwa besarnya pengaruh yang diberikan oleh disiplin kerja guru Bahasa Inggris terhadap mutu hasil belajar siswa sebesar 0,009 atau $0,9 \%$ sedangkan sisanya $99,1 \%$ dipengaruhi oleh faktor lain. Ini menunjukkan bahwa pengaruh yang diberikan antara disiplin kerja guru dan mutu hasil belajar untuk mata pelajaran Bahasa Inggris sangat rendah.
Untuk persamaan regresi antara disiplin kerja guru Bahasa Inggris dan mutu hasil belajar siswa adalah $\mathrm{Y}=82,31-0,05 \mathrm{X}$. Koefisien regresi (b) bernilai negatif dan dilihat dari p-value sebesar 0,57>0,05; hal ini menunjukkan bahwa disiplin kerja guru Bahasa Inggris tidak berpengaruh terhadap mutu hasil belajar yang diperoleh siswa, karena ada faktor lain yang mempengaruhinya dan disiplin kerja guru dalam melaksanakan pembelajaran kurang maksimal. Sebaiknya disiplin kerja guru Bahasa Inggris Kelas IX SMP Negeri 14 Palembang perlu ditingkatkan sehingga mutu hasil belajar yang diperoleh dapat lebih meningkat.

Tabel 8. Hasil Analisis Regresi,Disiplin Kerja Guru Matematika terhadap Mutu Hasil Belajar Siswa

\section{SUMMARY OUTPUT}

\begin{tabular}{|l|r|}
\hline \multicolumn{2}{|l|}{ Regression Statistics } \\
\hline Multiple R & 0.055860846 \\
\hline R Square & 0.003120434 \\
\hline Adjusted R Square & -0.009996402 \\
\hline Standard Error & 9.308850519 \\
\hline Observations & 318 \\
\hline
\end{tabular}


ANOVA

\begin{tabular}{|c|c|c|c|c|c|}
\hline & $D f$ & $S S$ & $M S$ & $F$ & $\begin{array}{c}\text { Significance } \\
F\end{array}$ \\
\hline Regression & 1 & 20.61475 & 20.61475 & 0.23789533 & 0.627134475 \\
\hline Residual & 316 & 6585.757 & 86.6547 & & \\
\hline Total & 317 & 6606.372 & & & \\
\hline & Coefficients & $\begin{array}{l}\text { Standard } \\
\text { Error }\end{array}$ & $t$ Stat & P-value & \\
\hline Intercept & 80.98546576 & 12.81455 & 6.319806 & $1.6276 \mathrm{E}-08$ & \\
\hline $\begin{array}{l}\text { Disiplin Kerja } \\
\text { Guru Matematika }\end{array}$ & -0.070565404 & 0.144677 & -0.48775 & 0.62713448 & \\
\hline
\end{tabular}

Berdasarkan tabel 8, hasil analisis regresi linear disiplin kerja guru matematika terhadap mutu hasil belajar, diperoleh nilai korelasi 0,05. Hal ini bermakna bahwa hubungan antara kinerja guru dan mutu hasil belajar sangat lemah. Koefisien determinan $\left(\mathrm{R}^{2}\right)$ sebesar 0,003 ; yang bearti bahwa besarnya pengaruh yang diberikan oleh disiplin kerja Matematika terhadap mutu hasil belajar siswa sebesar 0,003 atau 0,3\% sedangkan sisanya $99,7 \%$ dipengaruhi oleh faktor lain. Ini menunjukkan bahwa pengaruh yang diberikan antara disiplin kerja guru terhadap mutu hasil belajar untuk mata pelajaran Matematika sangat rendah.

Persamaan regresi linear antara disiplin kerja guru Matematika dan mutu hasil belajar siswa dalah $\mathrm{Y}=80,98-0,07 \mathrm{X}$. Koefisien regresi (b) bernilai negatif yaitu $-0,07$ dan dilihat dari p-value sebesar 0,63 > 0,05; hal ini menunjukkan bahwa disiplin kerja guru Matematika tidak berpengaruh terhadap mutu hasil belajar yang diperoleh siswa, karena pembelajaran terpusat pada guru dan sebaiknya siswa yang lebih aktif serta ada faktor lain yang mempengaruhinya.

Selanjutnya peneliti melakukan wawancara dengan responden pada penelitian ini khususnya kepada siswa, guru sudah baik dalam memberikan pelajaran tetapi metode yang digunakan oleh guru adalah metode ceramah. Menurut siswa, disiplin kerja guru matematika sudah baik karena setelah penjelasan materi dan memberikan contoh soal beserta penyelesaiannya membuat siswa memahami apa yang telah dipelajari, namun setelah diberikan soal yang berbeda siswa menjadi bingung. Hal ini disebabkan oleh kurangnya partisipasi siswa dalam menemukan konsep matematika. Sehingga dapat dinyatakan faktor yang mempengaruhi mutu hasil belajar matematika adalah metode pembelajaran yang digunakan oleh guru. Selanjutnya dalam proses pembelajaran di kelas siswa tidak diarahkan untuk menemukan konsep matematika, guru selalu dominan dalam proses pembelajaran.

Tabel 9. Hasil Analisis Regresi, Disiplin Kerja Guru IPA terhadap Mutu Hasil Belajar Siswa

\begin{tabular}{|l|r|}
\hline \multicolumn{2}{|c|}{ RUMMARession Statistics } \\
\hline Multiple R & 0.192443314 \\
\hline R Square & 0.037034429 \\
\hline Adjusted R Square & 0.010285386 \\
\hline Standard Error & 8.795673116 \\
\hline Observations & 318 \\
\hline
\end{tabular}


ANOVA

\begin{tabular}{|l|r|c|c|c|r|}
\hline & \multicolumn{1}{|c|}{ Df } & \multicolumn{1}{c|}{$S S$} & $M S$ & $F$ & Significance $F$ \\
\hline Regression & 1 & 107.1114 & 107.1114 & 1.384514143 & 0.247055548 \\
\hline Residual & 316 & 2785.099 & 77.36387 & & \\
\hline Total & 317 & 2892.211 & & & \\
\hline & Coefficients & $\begin{array}{c}\text { Standard } \\
\text { Error }\end{array}$ & t Stat & P-value & \\
\hline Intercept & 90.22895467 & 12.75428 & 7.074406 & $2.62271 \mathrm{E}-08$ & \\
\hline $\begin{array}{l}\text { Disiplin Kerja } \\
\text { Guru IPA }\end{array}$ & 0.201816338 & 0.171517 & -1.17665 & 0.247055548 & \\
\hline
\end{tabular}

Berdasarkan tabel 9, Hasil analisis regresi linear disiplin kerja guru IPA terhadap mutu hasil belajar siswa, diperoleh nilai korelasi sebesar 0,19. Hal ini menyatakan bahwa hubungan antara variabel kinerja guru IPA dengan mutu hasil belajar yang diperoleh siswa adalah lemah. Koefisien determinan $\left(\mathrm{R}^{2}\right)$ sebesar 0,037; yang bearti bahwa besarnya pengaruh yang diberikan oleh kinerja guru IPA terhadap mutu hasil belajar siswa sebesar 0,037 atau $3,7 \%$ sedangkan sisanya $96,3 \%$ dipengaruhi oleh faktor lain.

Persamaan regresi antara disiplin kerja guru IPA terhadap mutu hasil belajar adalah $\mathrm{Y}=90,23-0,20 \mathrm{X}$. Nilai koefisien regresi (b) sebesar -0,20; Koefisien regresi (b) bernilai negatif dan dilihat dari $p$-value sebesar 0,24 > 0,05; hal ini menunjukkan bahwa disiplin kerja guru IPA tidak berpengaruh terhadap mutu hasil belajar yang diperoleh siswa, disiplin kerja guru IPA kurang maksimal dan perlu ditingkatkan dan ada faktor lain yang mempengaruhinya.

Berdasarkan hasil wawancara antara peneliti dengan siswa yang menjadi responden dalam penelitian ini, untuk mata pelajaran IPA khususnya biologi, guru tidak pernah mengajak siswa untuk praktek di laboratorium sehingga materi yang diberikan kepada siswa hanya teori - teori saja yang terdapat di buku paket. Selanjutnya untuk fisika, siswa hanya diperkenalkan dengan rumus dan simbol - simbol, mereka kurang memahami makna dari simbol tersebut. Kemudian guru memberikan contoh soal. Ketika siswa menyelesaikan soal dengan tipe yang berbeda, mereka mulai bingung karena kesulitan dalam menterjemah kalimat soal ke simbol rumus yang diberikan. Ini membuktikan bahwa metode pembelajaran yang digunakan oleh guru adalah metode pembelajaran konvensional, sehingga siswa menjadi bosan dan mutu hasil belajar yang diperoleh siswa tidak maksimal. Seharusnya guru menggunakan metode pembelajaran yang beragam sesuai dengan karakteristik pembelajaran. Inilah yang menjadi penyebab bahwa antara kinerja guru IPA dan mutu hasil belajar yang diperoleh siswa tidak berpengaruh.

Berdasarkan penelitian sebelumnya yaitu Abdul Naser (2012) dan Asmawati (2017) yang menyatakan bahwa disiplin kerja guru mempengaruhi mutu hasil belajar siswa adalah benar tetapi tidak untuk semua pelajaran.Semakin baik disiplin kerja guru maka semakin baik pula mutu hasil belajar yang diperoleh siswa. Pada saat disiplin kerja guru kurang maksimal maka tidak akan mempengaruhi nilai yang diperoleh siswa.

Pembelajaran yang terpusat pada guru menyebabkan siswa kurang aktif sehingga mutu yang diperolehpun kurang maksimal. Selanjutnya, penelitian ini menyatakan bahwa metode pembelajaran yang digunakan guru dalam mengajar memegang peranan yang penting sehingga mutu hasil belajar yang diperoleh siswa menjadi lebih baik.

\section{KESIMPULAN}

Berdasarkan hasil analisis data dan pembahasan yang telah diuraikan maka dapat disimpulkan bahwa :

1. Penilaian disiplin kerja guru Bahasa Indonesia kelas IX SMP Negeri 14 
Palembang adalah 76,13 termasuk kategori baik dan mutu hasil belajar yang diperoleh siswa adalah 76,86 termasuk dalam kategori baik. Berdasarkan hasil analisis regresi linear diperoleh persamaan regresi antara disiplin kerja guru Bahasa Indonesia dan mutu hasil belajar adalah $\mathrm{Y}=$ $48,04+0,49 X$. Nilai koefisien regresi (b) sebesar 0,49 dengan t hitung 2,397 dan nilai signifikansi p-value sebesar 0,018 . Koefisien regresi bernilai positif menunjukkan bahwa arah pengaruhnya positif, artinya semakin baik kinerja guru Bahasa Indonesia maka mutu hasil belajar untuk mata pelajaran Bahasa Indonesia juga akan semakin baik. Selanjutnya nilai p-value sebesar 0,018 $<0,05$, sehingga dapat disimpulkan bahwa ada pengaruh antara kinerja guru Bahasa Indonesia terhadap mutu hasil belajar siswa. Semakin baik kinerja guru Bahasa Indonesia maka akan semakin maksimal mutu hasil belajar yang diperoleh siswa.

2. Penilaian disiplin kerja guru Bahasa Inggris 78,88 termasuk dalam kategori baik dan mutu hasil belajar yang diperoleh siswa sebesar 79,67 dengan kategori baik. Untuk persamaan regresi antara disiplin kerja guru Bahasa Inggris dan mutu hasil belajar siswa adalah $\mathrm{Y}=82,311-0,05 \mathrm{X}$. Koefisien regresi (b) bernilai negatif dan dilihat dari $p$-value sebesar $0,57>0,05$; ini menyatakan bahwa disiplin kerja guru Bahasa Inggris tidak berpengaruh terhadap mutu hasil belajar yang diperoleh siswa, karena disiplin kerja guru tersebut kurang maksimal dan ada faktor yang mempengaruhinya, salah satunya metode pembelajaran yang digunakan oleh guru dan pelajaran tambahan yang diikuti siswa di luar sekolah.

3. Penilaian disiplin kerja guru Matematika sebesar 78,27 yang berkategori baik sedangkan mutu hasil belajar yang diperoleh siswa sebesar 74,77 termasuk dalam katergori baik.
Persamaan regresi antara variabel disiplin kerja guru dan mutu hasil belajar adalah $\mathrm{Y}=80,98-0,07 \mathrm{X}$. Berdasarkan hasil analisis regresi linear tersebut dinyatakan bahwa hubungan variabel antara disiplin kerja guru matematika dan mutu hasil belajar siswa sangat rendah. Nilai koefisien (b) bernilai negatif yaitu $-0,07$ dan nilai $p$ value sebesar 0,64 > 0,05 sehingga dinyatakan bahwa tidak ada pengaruh antara disiplin kerja guru terhadap mutu hasil belajar siswa. Hal ini disebabkan ada faktor lain yang mempengaruhi mutu hasil belajar siswa. Salah satunya metode pembelajaran yang digunakan oleh guru dan seharusnya siswa digiring supaya aktif dalam pembelajaran dan penemuan konsep matematika.

4. Penilaian disiplin kerjaguru IPA adalah 73,89 termasuk dalam kategori baik sedangkan mutu hasil belajar yang diperoleh siswa adalah 72,89 berkategori baik. Persamaan regresi antara kinerja guru IPA dan mutu hasil belajar adalah $\mathrm{Y}=90,23-0,20 \mathrm{X}$. Berdasarkan hasil analisis regresi linear hubungan variabel antara disiplin kerja guru IPA dan mutu hasil belajar siswa dinyatakan sangat rendah. Nilai koefisien (b) bernilai negatif yaitu 0,20 dan nilai $\mathrm{p}$-value sebesar $0,24>$ 0,05 sehingga dapat dinyatakan bahwa tidak ada pengaruh antara kinerja guru terhadap mutu hasil belajar siswa untuk mata pelajaran IPA. Hal ini disebabkan oleh cara guru dalam mengajar materi biologi hanya terpusat pada buku paket dan materi fisika hanya pembahasan soal. Ini berarti metode pembelajaran yang digunakan oleh guru tidaklah tepat. Seharusnya guru menggunakan metode pembelajaran yang bervariasi dan disesuaikan dengan karakteristik materi.

5. Disiplin kerja guru setiap mata pelajaran mempengaruhi mutu hasil belajar siswa sekitar $10 \%$ dan ada faktor lain yang mempengaruhinya. 
Salah satunya adalah metode pembelajaran yang digunakan guru. Semakin baik disiplin kerja guru dalam melaksanakan pembelajaran maka akan semakin maksimal mutu hasil belajar yang diperoleh siswa.

6. Guru yang sudah lama mengajar belum tentu disiplin kerjanya dalam melaksanakan pembelajaran di kelas mempunyai kategori sangat baik. Sebagian besar guru hanya disiplin mengenai kehadiran namun disiplin untuk beberapa sub indikator yang lain perlu ditingkatkan lagi. Oleh karena itu guru harus tetap disiplin dalam melaksanakan pembelajaran di kelas misalnya menggunakan metode pembelajaran yang bervariatif dan sesuai dengan karakteristik materi, apersepsi diawal pembelajaran, penggunaan media atau alat peraga, memberikan komentar terhadap tugas siswa, memotivasi siswa supaya aktif dalam belajar, dan penarikan kesimpulan diakhir pembelajaran.

\section{DAFTAR PUSTAKA}

Asmawati.2017. Pengaruh Kinerja Guru terhadap Mutu Hasil Belajar Siswa Sekolah Dasar di Kecamatan Larompong Kabupaten Luwu.Journal of Mathematics Education.Vol. 2, No. 1, ( pp. $44-53$ ).

Fernandes, H.J.X. 1984. Testing and Measurement. Jakarta: National Education Planing, Evaluation and Curricuoum Development.

Kaplan, R.M, \& Saccuzzo, D.P. 1982. Psychological Testing: Principles, Application, and Issues. Monterey: Brooks/Cole Publishing Company.
Naser, A. 2012. Analisa Pengaruh Disiplin Kerja Guru terhadap Prestasi Anak Didik pada SLTP Negeri 1 Tanjung Bintang. Jurnal Organisasi dan Manajemen. Vol. 2, No. 1, (pp. 1-9). Nurmiati. 2013. Pengaruh Kinerja Guru dan Motivasi Belajar terhadap Hasil Belajar Siswa pada Mata Pelajaran Ekonomi di SMP Negeri 1 Rao Selatan Kabupaten Pasaman. Universitas Negeri Padang. Skripsi (unpublish).

Senduperdana, A. 2007. Analisis Hasil Belajar Mata Kuliah Umum: Survei di Fakultas Ilmu Administrasi Universitas Krisnadwipayanan Jakarta. Dalam Jurnal Pendidikan dan Kebudayaan, Januari 2007, tahun ke-13 no. 064. (pp. 47-70)

Setiyo, M., Waluyo, B., Purnomo, B. C., Munahar, S., Widodo, N., \& Rusdjijati, R. (2018). Evaluasi Ketercapaian Standar Penjaminan Mutu Penelitian Di Program Studi D3 Mesin Otomotif Universitas Muhammadiyah Magelang Dengan Metode Indeks. Jurnal Penjaminan Mutu, 4(1), 48-57.

Sudjana, Nana. 2002. Dasar - dasar Proses Belajar dan Mengajar. Bandung; Sinar Baru Algesindo.

Syam, A. 2016. Pengaruh Kepemimpinan Situasional dan Pemberian Reward terhadap Kinerja Guru Sekolah Menengah Kejuruan (SMK) Negeri 1 Kota Jambi.Jurnal Pendidikan dan Keguruan, 1(1).

Widoyoko, S.E.P \& Rinawati, A. 2012. Pengaruh Kinerja Guru terhadap Motivasi Belajar Siswa. Jurnal Cakrawala Pendidikan. Vol. XXXI, No. 2, (pp.278-289). 